\title{
Role of Insulin Secretagogues in the Regulation of Somatostatin Binding by Isolated Rat Islets
}

\author{
Philip S. Mehler, Ann L. Sussman, Arie Maman, J. Wayne Leitner, and \\ KARL E. Sussman, Veterans Administration Medical Center and Department \\ of Medicine, University of Colorado School of Medicine, Denver, Colorado 80220
}

A в S T R A C T To study the possible role of the secretion vesicle in ligand-receptor interaction, somatostatin binding was measured in islets in the presence of various substances known to promote secretion vesicle migration and fusion with the plasma membrane and insulin release. Rat islets were incubated with glucose, 30 and $300 \mathrm{mg} / \mathrm{dl}$, for $60 \mathrm{~min}$. After incubation, somatostatin binding was measured. In islets preincubated with glucose, $300 \mathrm{mg} / \mathrm{dl}$, somatostatin binding was increased $250 \%$ when compared with glucose, $30 \mathrm{mg} / \mathrm{dl}$ $(P<0.001)$. Concomitant with enhanced somatostatin binding, insulin secretion was increased. Galactose, $300 \mathrm{mg} / \mathrm{dl}$, did not stimulate insulin release, and somatostatin binding was unchanged from control levels. The increase in somatostatin binding with glucose was accounted for by a $186 \%$ increase in receptor concentration with no change in receptor affinity. Tolbutamide increased somatostatin binding by more than twofold, accompanied by a similar increase in insulin release. Secretion vesicles isolated from the islet exhibited somatostatin binding. We conclude that, first, somatostatin binding is increased concomitantly with the migration and fusion of the secretion vesicle with the plasma membrane and/or the release of insulin; second, enhanced somatostatin binding occurs as a consequence of an increased receptor concentration; and third, augmented somatostatin binding occurring with hormone release may provide a critical constraint in the regulation of secretory events.

\section{INTRODUCTION}

In cell systems capable of secreting polypeptide hormones, the secretion vesicle may play a multifaceted

This paper was presented in part before the Western Society for Clinical Research, Carmel, Calif., 1980.

Address reprint requests to Karl E. Sussman, Veterans Administration Medical Center, Box 111H, 1055 Clermont, Denver, Colo. 80220.

Received for publication 28 February 1980 and in revised form 11 August 1980. role. The primary function of the secretion vesicle is to act as a reservoir for storage of hormone and to facilitate intracellular transport of hormones $(1,2)$. Secretory products are probably undergoing some processing within the vesicle $(1,3)$. The secretion vesicle itself may also exert some role relative to the regulation of hormone secretion. This is suggested by the observations that the secretion vesicles isolated from pancreatic islets and the anterior pituitary gland possess cyclic AMP-dependent protein kinase activity $(4,5)$. Furthermore, it has been demonstrated that somatostatin specifically inhibits this protein kinase (6).

Secretion vesicles isolated from the anterior pituitary gland were found to bind somatostatin with an affinity exceeding that observed in plasma membranes, and were fivefold richer in somatostatin binding sites (7). We have proposed the thesis that during the process of emiocytosis, the secretion vesicle may bring to the plasma membrane an effector unit (i.e., cyclic AMPdependent protein kinase), as well as a high-affinity binding site for somatostatin (7).

If this thesis is correct, one would anticipate that during the process of emiocytosis and hormone release, cellular binding of somatostatin would be enhanced. The purpose of the present study is to measure somatostatin binding in isolated rat islets under the influence of various secretagogues that are known to promote secretion vesicle migration and insulin release.

\section{METHODS}

Materials. Collagenase (CLS-IV, $163 \mathrm{U} / \mathrm{mg}$ ) was obtained from the Worthington Biochemical Corp., Freehold, N. J. ${ }^{125} \mathrm{I}-\mathrm{Na}(>350 \mathrm{mCi} / \mathrm{ml} ; \sim 17 \mathrm{Ci} / \mathrm{mg} \mathrm{sp}$ act) was purchased from New England Nuclear, Boston, Mass. Cyclic somatostatin (SRIF) used in these studies was purchased from Beckman Instruments, Inc., Spinco Div., Palo Alto, Calif. $\mathrm{Tyr}^{1}$-somatostatin for iodination was kindly supplied by Dr. Jean Rivier of the Salk Institute, La Jolla, Calif. The somatostatin antibody for measurement of immunoreactive somatostatin was supplied by Dr. John Gerich, Mayo Clinic Graduate

${ }^{1}$ Abbreviations used in this paper: SRIF, cyclic somatostatin; TRH, thyrotropin-releasing hormone. 
School, Rochester, Minn. Sephadex G-25 and dextran T70 were purchased from Pharmacia Fine Chemicals, Inc., Piscataway, N. J.

Isolation of islets and secretion vesicles. Male SpragueDawley rats weighing $300-450 \mathrm{~g}$ were obtained from the Simonson Laboratories, Gilroy, Calif. The animals were allowed food and water ad lib. Anesthesia was induced with pentobarbital (Diabutal), $45 \mathrm{mg} / \mathrm{kg}$ body wt. Pancreatic islets were isolated by the method of Lacy and Kostianovsky (8) and subjected to the Ficoll gradient separation of Shibata et al. (9). The isolated islets were collected using a micropipette and preincubated for $30 \mathrm{~min}$ at $37^{\circ} \mathrm{C}$ in Krebs-Ringer bicarbonate buffer containing $30 \mathrm{mg} / \mathrm{dl}$ glucose and $1 \mathrm{mg} / \mathrm{ml}$ bovine serum albumin (BSA). The buffer had been previously gassed with $95 \% \mathrm{O}_{2} / 5 \% \mathrm{CO}_{2}$ for $45 \mathrm{~min}$ and adjusted to $\mathrm{pH}$ 7.4. Islet secretion vesicles were isolated according to the method of Leitner et al. (10).

Iodination procedure. $\mathrm{Tyr}^{1}$-somatostatin was labeled with ${ }^{125} \mathrm{I}$ according to the method of Harris et al. (11). ${ }^{125} \mathrm{I}-\mathrm{Tyr}^{1}$ somatostatin was eluted from a Sephadex G-25 (fine) column $(1.5 \times 60 \mathrm{~cm})$ with $0.1 \mathrm{M}$ acetic acid containing $0.1 \%$ gelatin. The peak immunoreactive labeled product, as determined by the method of Gerich et al. (12), had a specific activity $>140$ $\mathrm{Ci} / \mathrm{mmol}$.

Incubation protocol for insulin release and somatostatin binding studies. Following preincubation, 10 islets were transferred into a series of $12 \times 75$-mm glass tubes containing 200 $\mu l$ of the gassed Krebs-Ringer buffer with $30 \mathrm{mg} / \mathrm{dl}$ glucose and $1 \mathrm{mg} / \mathrm{ml} \mathrm{BSA}$ at $2^{\circ} \mathrm{C}$. This was followed by the addition of 800 $\mu \mathrm{l}$ of gassed Krebs-Ringer bicarbonate buffer containing 1 $\mathrm{mg} / \mathrm{ml} \mathrm{BSA}$ and sufficient glucose and/or tolbutamide to yield final concentrations of $300 \mathrm{mg} / \mathrm{dl}$ glucose, $30 \mathrm{mg} / \mathrm{dl}$ glucose, and $30 \mathrm{mg} / \mathrm{dl}$ glucose plus $400 \mu \mathrm{g} / \mathrm{ml}$ tolbutamide. In those experiments designed to study the effect of galactose on somatostatin binding and insulin release, similar buffers were prepared with galactose being substituted for glucose. The sample tubes were then incubated at $37^{\circ} \mathrm{C}$ for $1 \mathrm{~h}$, cooled to $2^{\circ} \mathrm{C}$ for $5 \mathrm{~min}$ and centrifuged at $800 \mathrm{~g}$ for $5 \mathrm{~min}$ at $4^{\circ} \mathrm{C}$. An 800 $\mu \mathrm{l}$ aliquot of the medium was carefully removed from each tube for determination of insulin release by double antibody radioimmunoassay. The islets in the remaining media were saved for somatostatin binding studies (referred to as incubated islets).

The technique for determining somatostatin binding described elsewhere has been modified and applied to intact islets and isolated secretory vesicles $(7,13,14)$. A buffered medium $(900 \mu \mathrm{l})$ consisting of $25 \mathrm{mM}$ EDTA, $0.1 \% \mathrm{BSA}$, and $500 \mathrm{KIU} / \mathrm{ml}$ Trasylol in $50 \mathrm{mM}$ Tris, $\mathrm{pH} 8.0$, was added to the $200 \mu \mathrm{l}$ of medium containing the incubated islets. Finally, 15 $\mu \mathrm{l}$ of label containing $2 \mathrm{ng}{ }^{125} \mathrm{I}-\mathrm{SRIF}(250,000 \mathrm{cpm})$ was introduced into the incubation medium. In the studies directed at determining displacement of labeled SRIF, $900 \mu \mathrm{l}$ of buffered medium containing unlabeled SRIF was added to yield final concentrations of $0,0.01,0.025,0.05,0.1,0.5,1.0$, $2.5,5.0$, or $20 \mu \mathrm{g} / \mathrm{ml}$. In all studies, samples were prepared in triplicate. Three "total count" tubes were included in each incubation. All preparatory steps were carried out at $2^{\circ} \mathrm{C}$, and binding was determined by incubation of the samples at $4^{\circ} \mathrm{C}$ for $18 \mathrm{~h}$.

The binding reactions were terminated by centrifuging the samples at $800 \mathrm{~g}$ for $5 \mathrm{~min}$ at $4^{\circ} \mathrm{C}$. A $900-\mu \mathrm{l}$ aliquot of the medium was removed and discarded (without disturbing the islet pellet). Ice-cold ethanol was added to the islets and remaining medium to yield a final concentration of $85 \%$ (vol/ vol). The samples were allowed to stand at $2^{\circ} \mathrm{C}$ for a period of $10 \mathrm{~min}$ and then centrifuged at $1,800 \mathrm{~g}$ for $10 \mathrm{~min}$ at $4^{\circ} \mathrm{C}$. The entire supernate was carefully removed and discarded. Pellet radioactivity was determined in a Searle Analytic 1185 automatic gamma counting system (Searle Radiographics, Inc., Des Plaines, Ill.).
Specific binding was determined as the difference between the samples containing 0 and $20 \mu \mathrm{g} / \mathrm{ml}$ unlabeled SRIF, these representing "total binding" and "nonspecific binding," respectively. Nonspecific binding comprised $28 \pm 4 \%$ of total binding at the high glucose concentrations and $54 \pm 6 \%$ of total at low glucose levels. The absolute magnitude of nonspecific binding was not influenced by any of the treatments employed in these experiments and represented $0.36 \pm 0.05 \%$ of the total available radioactivity.

Dissociation constants were calculated by least squares regression analysis, and where appropriate, statistical analyses were performed utilizing Student's $t$ test for unpaired data.

Finally, studies were directed at determining possible somatostatin binding by isolated islet secretion vesicles. Secretory vesicles were obtained from 2,000 islets. This fraction contained $5.8 \%$ of the total protein and $42.8 \%$ of the total insulin content. Thus, the secretion vesicle fraction represented an 18-fold enrichment in insulin content (microunits per microgram protein) when compared with homogenate. The purity of this fraction has been established in previous publications $(10,15)$.

The vesicles were suspended in $50 \mathrm{mM}$ Tris, $\mathrm{pH}$ 8.0. Total and nonspecific somatostatin binding was determined by adding $100 \mu \mathrm{l}$ of appropriate buffer reagent to a $100-\mu \mathrm{l}$ aliquot of the secretory vesicle fraction containing $10 \mu \mathrm{g}$ protein. Introduction of label, incubation, and termination of the binding reaction were as before.

\section{RESULTS}

Fig. 1 demonstrates that when isolated rat islets were incubated with $300 \mathrm{mg} / \mathrm{dl}$ glucose as compared with 30 $\mathrm{mg} / \mathrm{dl}$ glucose, somatostatin binding was increased
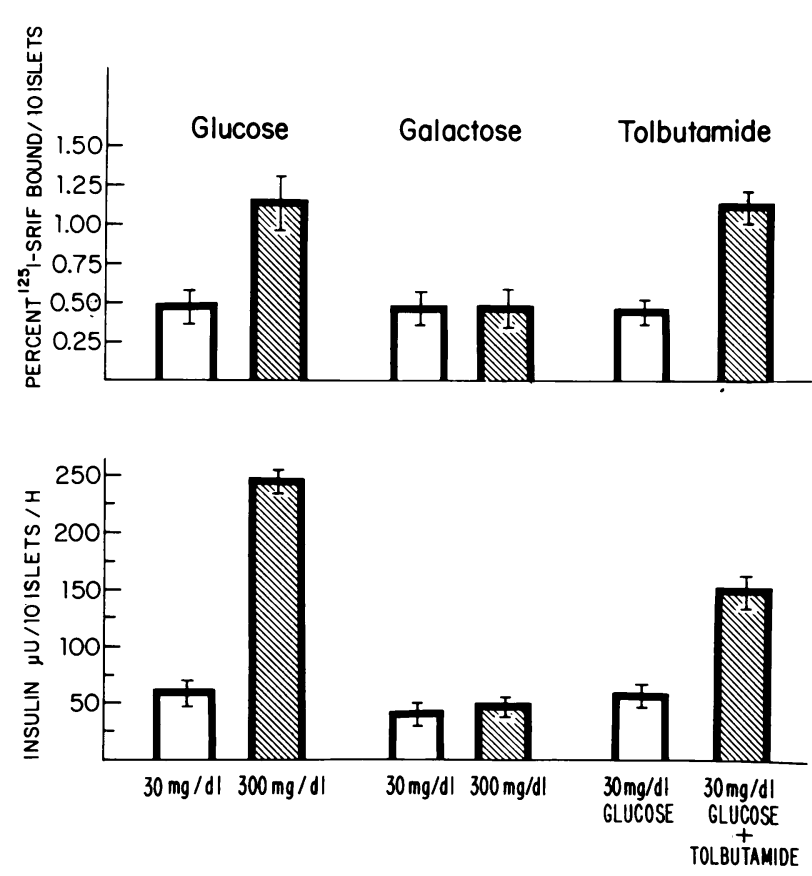

Figure 1 Somatostatin binding (upper bar graph) and insulin release (lower bar graph) in isolated pancreatic islets incubated with glucose $(n=25)$, galactose $(n=10)$, or tolbutamide $(n=8)$. Shown is the percent of somatostatin bound per 10 islets corrected for nonspecific binding. Values are mean $\pm S E M$. 
$249 \pm 35 \%(P<0.001)$. Concomitantly with the increases in somatostatin binding, insulin levels increased from $58 \pm 4$ to $250 \pm 8 \mu \mathrm{U} / \mathrm{ml} \quad(P<0.001)$. In contrast, incubation in similar concentrations of galactose produced no similar enhancement of somatostatin binding. No increase in insulin secretion was observed with galactose, which is consistent with previous observations in this regard $(16,17)$. Tolbutamide $(400$ $\mu \mathrm{g} / \mathrm{ml}$ ) increased somatostatin binding by $265 \pm 14 \%$ $(P<0.001)$. In this setting, insulin levels increased from $53 \pm 8$ to $151 \pm 16 \mu \mathrm{U} / \mathrm{ml}(P<0.001)$.

Islets were incubated at insulin concentrations that reflected the levels of insulin release obtained at a glucose level of $300 \mathrm{mg} / \mathrm{dl}$. Under these circumstances somatostatin binding was not increased. Thus, the effect of glucose in enhancing somatostatin binding could not be attributed to increased media insulin levels.

Fig. 2 demonstrates the displacement of labeled somatostatin by the addition of unlabeled somatostatin. The displacement curves show somatostatin binding in islets that have been incubated at both high and low glucose concentration. At all levels of added somatostatin, those islets incubated in a glucose concentration of $300 \mathrm{mg} / \mathrm{dl}$ showed greater binding than those islets incubated at the lower glucose concentration. In conformity with previous data, there was no displacement of labeled somatostatin by two low molecular weight peptides, thyrotropin-releasing hormone (TRH) and luteinizing hormone releasing factor (13).

The displacement data analyzed according to the method of Scatchard (18) are shown in Fig. 3. It is apparent that the increase in somatostatin binding in those islets incubated in the high glucose concentration is not accompanied by a change in binding affinity. In contrast, the high-affinity receptor concentration (Ro). has increased from $1.53 \pm 0.28$ to $2.58 \pm 0.35 \times 10^{-10} \mathrm{M}$ in the islets incubated in glucose $(300 \mathrm{mg} / \mathrm{dl})$ as compared with the low glucose level $(P<0.001)$. These values have been corrected for the contribution of low-affinity binding. Whether the curvilinearity of the Scatchard plot represents negative cooperation or two classes of binding sites cannot be answered with the present data. Because the slopes of the low-affinity components are not significantly different, it is apparent that if one analyzes either the high-affinity components or the total curves (average affinity), the change in islet somatostatin binding with high glucose concentration is due to an increase in receptor concentration.

Previous studies relative to somatostatin binding in secretion vesicles were performed using bovine anterior pituitary glands (13). Because of the possible role of the secretion vesicle in modulating somatostatin binding, it was critical to establish that such binding exists in the secretion vesicle fraction isolated from rat islets. Total somatostatin binding by islet secretion vesicles was $2.11 \pm 0.3 \%$, of which $26.1 \pm 1.1 \%$ was nonspecific binding. Specific binding by the secretion vesicle was $1.71 \pm 0.39 \times 10^{-14} \mathrm{~mol} / \mu \mathrm{g}$ protein compared with $4.83 \pm 0.80 \times 10^{-15} \mathrm{~mol} / \mu \mathrm{g}$ protein for the intact islet.

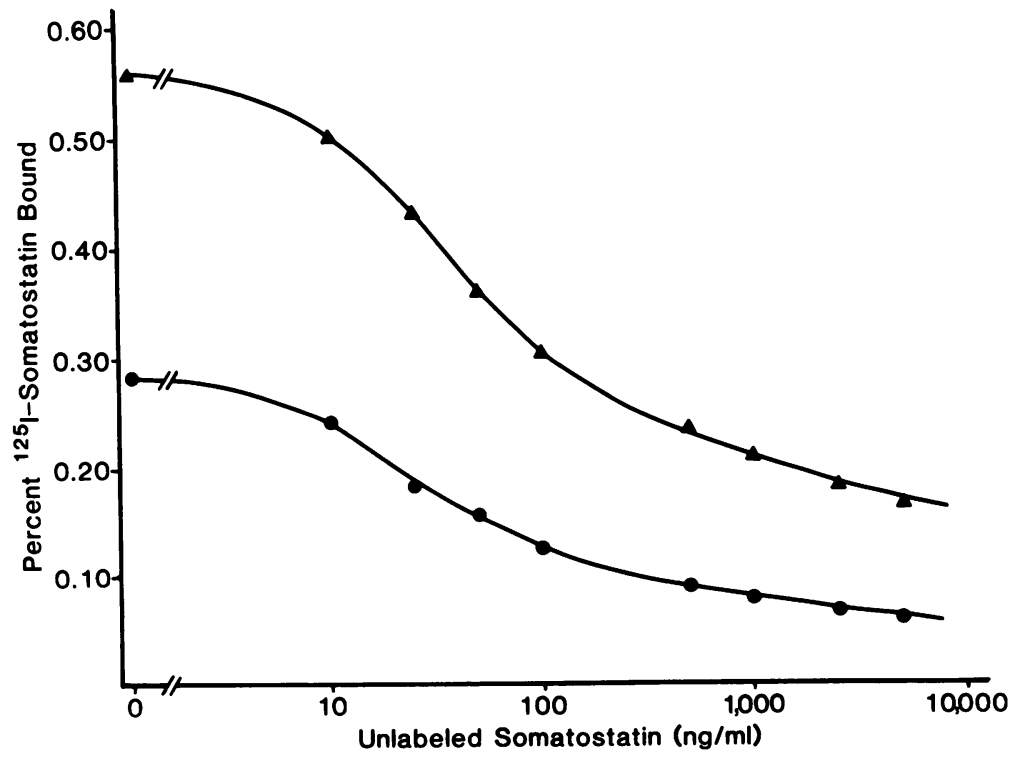

Figure 2 Competition curves for somatostatin. Displacement of labeled somatostatin by unlabeled somatostatin. Shown are mean values $(n=8)$ for binding obtained with islets incubated at glucose concentrations of $300 \mathrm{mg} / \mathrm{dl}(\boldsymbol{\Delta})$ and $30 \mathrm{mg} / \mathrm{dl}(\boldsymbol{O})$. 


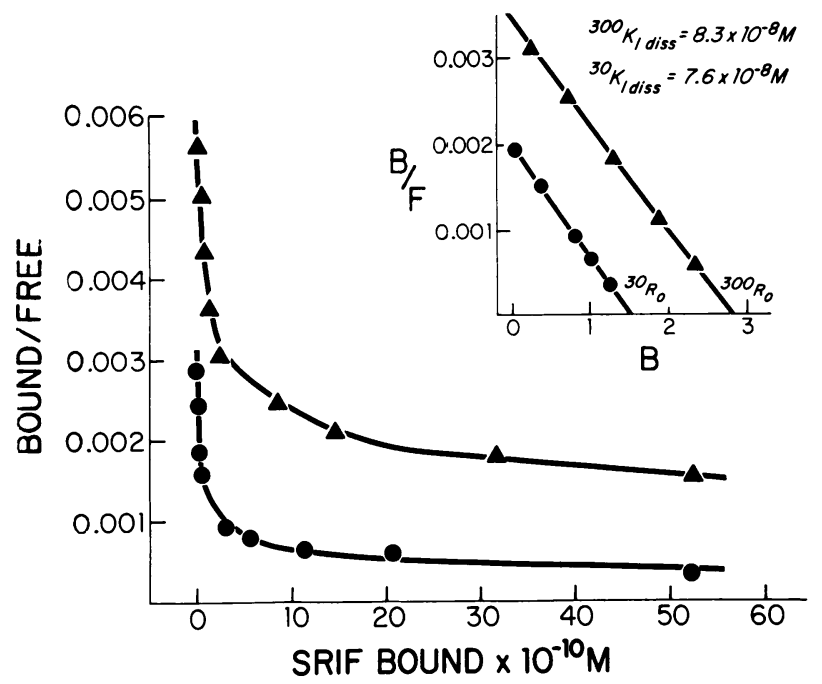

FIgURE 3 Scatchard analysis of somatostatin displacement data. Inset is a Scatchard plot for the high-affinity component corrected for the contribution of the low-affinity binding sites. Shown are the dissociation constants and the $\times$-intercepts (Ro) for 30 and $300 \mathrm{mg} / \mathrm{dl}$ glucose.

\section{DISCUSSION}

The present data suggest that with insulin secretion and/or the event of the migration and union of the secretion vesicle with the plasma membrane, somatostatin binding is enhanced. The data indicate that the enhanced binding of somatostatin associated with various insulin secretagogues occurs as a result of an increase in receptor concentrations rather than a change in binding affinity. Schonbrunn and Tashjian (19) reported increased binding of somatostatin in the presence of TRH in cultured pituitary tumor cells. As in the present study, the enhanced binding of somatostatin was related to an increase in the concentration of receptor sites with no change in affinity. These investigators postulated that TRH may exert its effect on the internalization or processing steps for the somatostatin receptor. Little is known about the kinetics of receptor degradation. Whether the various secretagogues may have altered the rates of internalization and/or degradation of the somatostatin receptor has not been investigated.

Previous data from this laboratory using subcellular organelles isolated from bovine anterior pituitary glands suggested that there exists a specific somatostatin binding site in the secretion vesicle (7). It was postulated that perhaps during the process of emiocytosis, the secretion vesicle confers upon the plasma membrane a high-affinity binding site for somatostatin. The present set of experiments performed in pancreatic islets is consistent with this thesis insofar as somatostatin binding is enhanced with various secretagogues, this enhancement being due to an increase in receptor concentration. This thesis is further supported by the fact that the islet secretion vesicles exhibited somatostatin binding activity that exceeds that found in the intact islet.

An alternate hypothesis is that, as a result of some change in the plasma membrane consequent to the event of hormone release, preexistent binding sites are unmasked, which allows an increased amount of somatostatin to be bound. This latter mechanism may involve the transfer of binding sites from the secretion vesicle to the plasma membrane during the process in which these two subcellular organelles become united. The possibility exists that somatostatin receptors are synthesized within the plasma membrane, and that the secretion vesicle exerts no function in modulating somatostatin binding. In the studies of Schonbrunn and Tashjian (19), the TRH-induced increase in somatostatin receptor number was not prevented when protein synthesis was inhibited by cycloheximide.

In any event, the net effect would be the same under each hypothesis; that is, as a result of various secretagogues promoting enhanced hormone release, the plasma membrane would undergo an alteration in which somatostatin binding is increased, thereby providing a possible constraint in modulating further glucose and tolbutamide-induced insulin release. However, the islets are a heterogeneous tissue, containing various cells that are known to be effected by somatostatin. Beta cells represent $75-80 \%$ of islet mass. Nevertheless, with glucose increasing somatostatin binding, it remains unanswered whether this phenomenon is also occurring in the glucagon-secreting alpha cell. Thus, the interrelationships may be quite complex within somatostatin binding and action.

With the present evidence, it is appropriate to conceive of the secretion vesicle as playing a critical role in modulating hormone release, rather than simply acting as a storage unit and as an intracellular hormone transport system. The secretion vesicle may play a dual role, possessing both the effector unit (i.e., cyclic AMPstimulated protein kinase) and the high-affinity binding receptor for somatostatin. The regulation of secretory events may be related to biochemical or molecular alterations occurring within the secretion cells at the junction of the secretion vesicle with the plasma membrane. In the case of somatostatin, this hormone would inhibit cyclic AMP-stimulated protein kinase activity at a specific locus in the cell (e.g., the junction of the secretion vesicle with the plasma membrane), rather than affecting a number of cellular processes which may be controlled by cyclic AMP-stimulated protein kinase.

While such a formulation may explain how the secretion vesicle may specifically control the events of hormone secretion, it does not explain the diverse actions of somatostatin in other tissues in which no 
secretion vesicles are present (e.g., the gastrointestinal tract). Nevertheless, in those tissues secreting hormones by a mechanism involving granule extrusion, this model of somatostatin binding and action and the role of the secretion vesicle therein is consistent with available data.

\section{ACKNOWLEDGMENTS}

The authors are indebted to Ms. Dorothy Toothaker for her technical assistance. We wish to express our appreciation to our secretary, Ms. Evelyn Fitzgerald. We also wish to thank Drs. B. Draznin, J. Olefsky, and O. G. Kolterman for their helpful comments.

This research was supported by the Medical Research Service of the Veterans Administration Medical Center (MRIS \#8227), Denver, Colo.; the Diabetes Research Foundation of Denver, Colo.; and the Upjohn Company, Kalamazoo, Mich.

\section{REFERENCES}

1. Palade, G. E. 1975. Intracellular aspects of the process of protein synthesis. Science (Wash. D. C.). 189: 347-358.

2. Lacy, P. E. 1975. Endocrine secretory mechanisms: a review. Am. J. Pathol. 79: 170-187.

3. Jamieson, J. D., and G. E. Palade. 1971. Condensing vacuole conversion and zymogen granule discharge in pancreatic exocrine cells. Metabolic studies. J. Cell Biol. 48: 503-522.

4. Labrie, F., S. Lemaire, G. Poirier, G. Pelletier, and R. Boucher. 1971. Adenohypophyseal secretory granules. I. Their phosphorylation and association with protein kinase. J. Biol. Chem. 246: 7311-7317.

5. Sussman, K. E., and J. W. Leitner. 1977. Cyclic AMP stimulated protein kinase activity within the secretory vesicle fraction of rat islets. Biochem. Biophys. Res. Commun. 79: 429-437.

6. Sussman, K. E., J. W. Leitner, and R. M. Rifkin. 1978. Somatostatin: selective inhibition of cyclic AMP stimulated protein kinase. Trans. Ass. Amer. Physicians. 91: 129-143.

7. Leitner, J. W., R. M. Rifkin, A. Maman, and K. E. Sussman.
1980. The relationship between somatostatin binding and cyclic AMP stimulated protein kinase inhibition. Metabolism. In Press.

8. Lacy, P. E., and M. Kostianovsky. 1967. Method for isolation of intact islets of Langerhans from the rat pancreas. Diabetes. 16: 35-39.

9. Shibata, A., C. W. Ludvigsen, Jr., S. P. Naber, M. D. McDaniel, and P. E. Lacy. 1976. Standardization of a digestion-filtration method for isolation of pancreatic islets. Diabetes. 25: 667-672.

10. Leitner, J. W., K. E. Sussman, A. E. Vatter, and F. H. Schneider. 1975. Adenine nucleotides in the secretory granule fraction of rat islets. Endocrinology. 96: 662-677.

11. Harris, V., J. M. Conlon, C. B. Srikant, K. McCorkle, V. Schusdziarra, E. Ipp, and R. H. Unger. 1978. Measurements of somatostatin-like immunoreactivity in plasma. Clin. Chim. Acta. 87: 275-284.

12. Gerich, J., K. Greene, M. Hara, R. Rizza, and G. Patton. 1979. Radioimmunoassay of somatostatin and its application in the study of pancreatic somatostatin secretion in vitro. J. Lab. Clin. Med. 93: 1009-1017.

13. Leitner, J. W., R. M. Rifkin, A. Maman, and K. E. Sussman. 1979. Somatostatin binding to pituitary plasma membranes. Biochem. Biophys. Res. Commun. 87: 919-927.

14. Schonbrunn, A., and A. H. Tashjian, Jr. 1978. Characterization of functional receptors for somatostatin in rat pituitary cells in culture. J. Biol. Chem. 253: 6473-6483.

15. Sussman, K. E., and J. W. Leitner. 1977. Conversion of ATP into other adenine nucleotides within isolated secretory vesicles. Effect of cyclic AMP on phosphorus translocation. Endocrinology. 101: 694-701.

16. Grodsky, G. M., A. A. Batts, L. L. Bennett, C. Vcella, N. B. McWilliams, and D. F. Smith. 1963. Effects of carbohydrates on secretion of insulin from isolated rat pancreas. Am. J. Physiol. 205: 638-644.

17. Sussman, K. E., G. D. Vaughan, and R. F. Timmer. 1966. An in vitro method for studying insulin secretion in the perfused isolated rat pancreas. Metabolism. 15: 466-476.

18. Scatchard, G. 1949. The attraction of proteins for small molecules and ions. Ann. N. Y. Acad. Sci. 51: 660-672.

19. Schonbrunn, A., and A. H. Tashjian, Jr. 1980. Modulation of somatostatin receptors by thyrotropin-releasing hormone in a clonal pituitary cell strain. J. Biol. Chem. 255: 190-198. 